\title{
A Critical Review of the CELTA Syllabus within the Context of Saudi Arabia
}

\author{
Amjjad Sulaimani $^{1}$ \& Tariq Elyas ${ }^{2}$ \\ ${ }^{1}$ English Language Institute, King Abdulaziz University, Jeddah, Saudi Arabia \\ ${ }^{2}$ Faculty of Arts and Humanities, European Languages Department, King Abdulaziz University, Jeddah, Saudi \\ Arabia \\ Correspondence: Amjjad Sulaimani, English Language Institute, King Abdulaziz University, Jeddah, 21589, \\ Saudi Arabia. E-mail: amjjadsulimani@gmail.com
}

Received: January 17, 2015 Accepted: February 11, 2015 Online Published: March 29, 2015

doi:10.5539/ijel.v5n2p100 URL: http://dx.doi.org/10.5539/ijel.v5n2p100

\begin{abstract}
The focus of this paper is on the cultural aspects of the internationally, well-recognised and accepted international teacher training course known as Certificate in English Language Teaching to Adults (CELTA), or rather, the lack of it. In what follows, we will first discuss the various aspects related to the importance of culture and its inclusion in the field of English Language Teaching (ELT). Next, we will discuss the main highlights of the CELTA course and its main components and present a practical suggestion for implementing a short 'culture' component that can be easily integrated into the course where it will increase cultural awareness amongst new teachers embarking on a career abroad in a foreign country and hopefully achieve pedagogical competence when working abroad.
\end{abstract}

Keywords: ESOL, CELTA, ELT, EFL, outer circle, inner circle, western culture, Saudi culture. Saudi Arabia, King Abdulaziz University, English Language Institute

\section{Introduction}

\subsection{The Cohort of the Problem}

Considered to be a short, initial training program for those with limited experience teaching English for Speakers of Other Languages (ESOL), the international teacher training course known as Certificate in English Language Teaching to Adults (CELTA) aims to equip ESOL teachers to teach in a variety of contexts around the world. However, a close examination of the CELTA syllabus indicates that practical teaching skills and teacher behaviour are predominant features of its curriculum, while cultural aspects of English language instruction are often neglected or overlooked. Ideally, training programs for language teachers should prepare teachers "not only in the technical knowledge of language of various discourses of related fields, but [should also focus on] the cultural and socio political issues that come with teaching English" (Troudi, 2006, p. 119). With such cultural awareness, teachers can ensure that every aspect of their practice is informed by a deep understanding of students' local culture, students' approaches to learning English, and students' identities as second or foreign language users.

This paper questions the absence of cultural aspects in the CELTA syllabus in the light of international teaching contextual features. It argues that CELTA course designer and other educators of novice English language teachers need to consider including some cultural knowledge components in their curricula, in this context, Saudi Arabia. It is our contention that the introduction of these elements can help these teachers to prepare lessons that address their students' sociolinguistic and communicative language needs based on their own contextual learning culture. Also, having a thorough understanding of such cultural knowledge issues can improve teachers' ability to fulfil their purpose of students learning of English language as well.

To achieve this end, we shall first define the concept of culture in English as a Foreign Language (EFL) instruction and explain its importance. Following a general description of the CELTA syllabus, we shall explain how CELTA attempts to produce 'robotic teachers' who often follow prescribed teaching strategies in order to be successful in their classrooms, without taking the local needs of their students into consideration. Lastly, we shall suggest the introduction of post-method pedagogy principles in the CELTA syllabus as an effective means for 
offering EFL teachers' better understanding of cultural knowledge issues, and finally we argue that greater awareness of the potential advantages of these pedagogical principles in their EFL teaching contests can help to improve their routine teaching practice.

\subsection{Cultural Knowledge}

\subsubsection{Definition of Culture in ELT}

It has been stated that the term culture in English Language Teaching (ELT) includes cognitive, affective, and behavioural components (Kumaravdivelu, 2003a). The cognitive component includes knowledge about the geography, lifestyle, values, and attitudes in the second language (L2) learners' community. The affective component refers to empathy for the L2 learners' culture. The behavioural component is related to the ability to interpret culturally relevant behaviour, and behave in culturally appropriate ways.

Troudi (2005) distinguishes between what he calls large and small cultures. According to him, "large culture refers to entities such as ethnicity, national and geographical boundaries, religion, language and their effects on people's everyday lives. In contrast, a small culture refers to any type of cohesive behaviour and shared definitions within a social group" (p. 121). The classroom is an example of small culture. Troudi views the classroom as a sociocultural community where students and teacher create shared goals and patterns of interaction. Such a project requires teachers to integrate both home-language culture and target-language culture in their classrooms. More precisely, teachers and students need to develop their own critical culture.

The concept of critical culture is based on the idea that "every cultural community has virtues to be proud of, and every cultural community has vices to be ashamed of" (Kumararvadivelu, 2003a, p. 284). In a classroom context, participants develop their own culture that incorporates all the best of the different cultures learners bring with them into the classroom. Highlighting the advantage of implementing the critical culture, Arffin (2006) argues that making use of both cultures in the classroom is valuable because students will be encouraged to discover similarities between their own and the target culture, rather than focusing on differences.

Many EFL teachers are concerned about the best way to understand culture. The exact same opinion has been argued by Liu (1998), as culture is "the best way to understand a culture is to be immersed in it" (p. 8). Approached in this way, culture is not viewed as a collection of static facts or discrete items but rather as a process, i.e., as a way of perceiving, interpreting, feeling, understanding, and being in the world.

\subsubsection{The Importance of Culture in ELT}

Kumaravdivelu (2003a) states that "no classroom is an island unto itself. Every classroom is influenced by and is a reflection of the larger society of which it is a part" (p. 252). This means that culture plays a significant role in language classrooms. How a learner learns the second language and uses it highly depends on the sum of the learner's prior experiences, the sociocultural contexts in which the learning takes place, and what the learner wants, needs, and/or is expected to do with that knowledge (Johnson, 2009).

Hence, culture plays a vital role in language classrooms for two reasons. First, cultural knowledge provides the basis for the content and topics used in classroom instructions and discussions. Second, teaching strategies are frequently chosen based on particular cultural models (McKay, 2003). In the Saudi teaching context, for example, communicative language teaching (CLT) is met with resistance from students most of the time. Saudi students perceive the teacher as a figure of authority and a source of knowledge (Elyas \& Picard, 2010), but CLT methodology leaves students feeling that the teacher is not doing his/her job properly. This proves that imposing a certain teaching methodology without considering the ways and minds of local people or respecting the culture of learning will trigger a rejection of the lesson that immediately hinders learning the second language.

By contrast, awareness of the L2 learners' culture will help the teacher design activities that accommodate students' personal differences and help them develop their individual identities (Elyas \& Picard, 2012). More than that, it allows learners to use the language to express their own cultural identity, in their local contexts, and on their own terms. In more accurate words, associating culture to ELT will give L2 learners the chance to become bilingual without being bicultural. Alpetkin and Alpetkin (2013) confirm that there has been an increase in disassociating the learning of the English language from its nationality-bound cultural contexts. In the Saudi context, for instance, L2 learners reject the norms and values of the English-speaking cultures, but still acquire English satisfactorily. They are motivated to use the English language to express their own ideology, assumptions, and cultural basis rather than of the Englishmen. In this way the English language classroom is not just a context for the learning of isolated language skills, but a community of practice where ideologies and meanings are co-constructed and individual personalities are developed. 
Another example of the phenomenon of bilingualism without biculturalism in ELT is TESOL Islamia. The organization is developed by a group of ELT professionals in the Middle East in order to promote ELT in ways that best serve the socio-political, sociocultural and socioeconomic interest of the Islamic world (Kumaravdivelu, 2006a). One of their main goals is to promote and safeguard Islamic values in the ELT in the Muslim world.

\section{A General Overview of the CELTA Course and Its Components}

\subsection{Syllabus Overview}

Cambridge English for Teaching (2010) describes CELTA as "an introductory course for candidates who have little or no previous English language teaching experience” (p. 2). The syllabus covers five specific topic areas:

- $\quad$ Topic 1 Learners and teachers, and the teaching and learning context

- $\quad$ Topic 2 Language analysis and awareness

- $\quad$ Topic 3 Language skills: reading, listening, speaking and writing

- $\quad$ Topic 4 Planning and resources for different teaching contexts

- $\quad$ Topic 5 Developing teaching skills and professionalism (ibid).

These topics are delivered via lectures, tutorial support, supervised lesson planning, supervised teaching practice, and teaching feedback (Hobbs, 2013). The course involves 120 hours of tutor contact e.g. input, supervised lesson planning and feedback, six hours of assessed teaching practice for each trainee, and six hours of observation of experienced teachers.

\subsection{Topic Descriptions}

The first topic, learners, teachers, and the teaching and learning context, provides candidates with a general understanding of the range of backgrounds and experiences that adult learners bring to their classes, including the different motivations and expectations that adults bring to learning English. In particular, it seeks to raise awareness of the ways in which personal factors may affect language learning, and of the different learning styles and preferences that adults bring to learning English (Cambridge English for Teaching, 2010).

Topic 2, Language analysis and awareness, provides a framework for grammatical rules, word formation, and English phonemes. Topic 3, Language skills: reading, listening, speaking and writing, introduces the basic features of written texts, spoken English, and listening texts. It also introduces key teaching strategies and approaches for developing learners' receptive and productive skills. Topic 3, Planning and resources for different teaching contexts, introduces principles of effective planning and teaching and encourages candidates to select, adapt, and evaluate materials and resources in planning. Finally, Topic 5, Developing teaching skills and professionalism, explores the practical skills required for teaching at a range of levels, the use of teaching materials and resources, and the evaluation of the teaching and learning process.

\subsection{Assessment}

Candidates are assessed by CELTA tutors throughout the course. There are two areas of assessment, written assignments and planning and teaching (Cambridge English for Teaching, 2010). Candidates are required to submit four written assignments, the first of which focuses on adult learners and learning contexts. The second assignment is focused on aspect of the language system of English, and the third on an aspect of language skills. The fourth and final assignment asks candidates to reflect on their classroom teaching and identify action points through which to improve and develop their learning and practice.

In addition to these four assignments, candidates must teach for a total of six hours, working with classes at two levels of ability (e.g., Elementary and Intermediate levels). Assessment is based on the candidate's overall ability in the classroom during the six hours of teaching practice.

\subsection{The Neglect of Culture in the CELTA: The Pedagogical Outcome}

Many international trainees are enrolled in the CELTA program. The program is offered by several Cambridge-accredited teaching training centres around the world. In spite of their different backgrounds and needs, these trainees are usually given the same training as their monolingual English speaking peers. They are introduced to many teaching methodologies that are dominant in Western-English speaking countries, but may be considered impractical in most non-English speaking countries (Liu, 1998).

This unified training produces a gap between what multi-lingual trainees learn during the CELTA course and what they face in their real classrooms back home. This gap has a harmful effect on the local teaching environment of many trainees. As a consequence, CELTA holders often are confronted with two problems: first, 
the conflict between their newly acquired methodologies and those that are still firmly followed by local professionals and second, the dilemma of whether or not to compromise these methods and techniques to match the local needs of the learners.

Our own experience of teaching English in a Saudi context illustrates this point. As in most non-English speaking countries, English is treated as a required academic subject in Saudi Arabia, rather than as a tool for survival in business and education. The language classrooms are large (a minimum of 30 students), the teacher is seen as a fount of knowledge, and the method of instruction is teacher-cantered (Elyas \& Picard, 2010). Considering these factors, a newly qualified, CELTA-holding teacher will face strong resistance from students when implementing Western-oriented methodologies such as communicative language teaching (CLT), for three reasons. First, students will not realize the need of communicating the language because they only need to understand how the language works in order to pass the subject. Second, monitoring and facilitating thirty students while communicating will be challenging, if not impossible, for an inexperienced teacher. Third, many students who are used to the traditional teacher-cantered way of instruction will complain that the teacher is not doing his/her job properly.

This view is shared by Pennycook (1989), who proclaims that the concept of method "reflects a particular view of the world and is articulated in the interests of unequal power relationship" (p. 589). In our view, the teaching methodologies proposed in the CELTA program view teaching English as an inner-circle language rather than an international language. The problem of inner-circle ELT programs is that they prepare trainees to function in the inner circle countries, but not in a course that teaches English in the expanding circle countries (Matsuda, 2003). For example, teaching inner-circle English in Saudi Arabia neglects the real linguistic needs of the learners, overshadows their Islamic culture, and fails to empower them with ownership of English.

Phillipson (2008) writes that "the professional discourse around ELT disconnects culture from structure by limiting the focus in language pedagogy to technical matters, that is, language and education in a narrow sense" (p. 48) and excluding social, economic, and political matters. Sharing this view, Murray (2009) criticizes the CELTA program for its focus on technical teaching strategies, leading to the neglect of the social and intellectual realms. In her view, the effect of this narrow focus devalues the teacher's autonomy and creates a teaching framework which has no place in the local teaching context. Prabhu (1990) supports Murray's call for teacher autonomy when arguing that teachers need to "operate with some personal conceptualization of how their teaching leads to desired learning" (p. 172).

From the above discussion of teacher's autonomy it may be inferred that CELTA promotes robotic language teachers who often follow prescribed teaching strategies in order to be successful in their classrooms, without taking the local and cultural needs of their students into consideration. These robotic language teachers have adequate ability in terms of lesson planning, choosing activity, and imposing different teaching methodologies. However, despite the importance of these elements in teaching, their ability to make informed pedagogical choices does not necessarily follow from them (Hobbs, 2013). CELTA robotic trainees do not have the ability to think critically about teaching and teaching contexts, and as a consequence they cannot generate innovative practices which are particular to their local classrooms.

\subsection{The Postmethod Pedagogy}

\subsubsection{A Practical Way to Implement Culture in Teaching}

Simply infusing an introductory course on cultural awareness into the CELTA syllabus is unlikely to bring about the kind of paradigm shift that is aimed for. Instead, along with the knowledge of the local culture, teachers must gain competence in constructing pedagogical practices that are sensitive to the local society, culture, and learners. One possible way to achieve this is to incorporate into teacher training programs such as CELTA a course on postmethod pedagogy. The postmethod signifies the possibility of incorporating the local culture into the EFL pedagogy. The concept of the postmethod can be summarized as follows:

The postmethod perspective seeks to equip student teachers with the knowledge, skill, attitude, and autonomy necessary to devise for themselves a systematic, coherent, and relevant theory of practice. It promotes the ability of teachers to know how to develop a reflective approach to their own teaching, how to analyse and evaluate their own teaching practice, how to initiate change in their classroom and how to monitor the effects of such changes (Kumararvadivelu, 2012, p. 10).

CELTA trainers introduce language teaching methods that are predominantly top-down, i.e., the conception and construction of these methods "have been largely guided by a one size-fits-all-cookie-cutter approach that assumes a common clientele with common goal" (ibid). However, as the above quote suggests, the postmethod 
pedagogy is a bottom-up process. The process requires both language teachers and teacher educators to use their professional and personal knowledge in order to devise a pedagogy that is sensitive to local needs, wants, and situations (Kumararvadivelu, 2003b).

The postmethod pedagogy consists of three parameters: particularity, practicality and possibility. The parameter of particularity calls for context-sensitive, location-specific pedagogy (Kumararvadivelu, 2006b). It emphasizes that language teaching "must be sensitive to a particular group of teachers teaching a particular group of learners pursuing a particular set of goals within a particular institutional context embedded in a particular sociocultural milieu" (Kumararvadivelu, 2001, p. 538). The parameter of practicality refers to the relationship between theory and practice. It enables and encourages teachers "to theorize from their practice and to practice what they theorize" (Kumararvadivelu, 2006b, p. 69). The parameter of possibility seeks to empower classroom participants to reflect critically on their socio-political and cultural knowledge. Such a reflection "should help [classroom participants] appropriate the English language and use in their own terms according to their own values and visions" (Kumararvadivelu, 2003b, p. 544).

\section{Conclusion}

Teacher education program designers in general and CELTA course designers in particular must take into account the cultural and socio-political issues that are relevant to the contexts of the second language learners. Incorporating cultural knowledge and socio-political issues into the CELTA syllabus not only would help language teachers acquire a basic starter pack of ELT methodologies, but it also would ensure that every aspect of the teacher's teaching practice is informed by a deep understanding of students' local intellectual conditions. Blending the postmethod pedagogy into the CELTA syllabus will facilitate teachers in devising a context-sensitive teaching practice, enabling "practitioners to generate location-specific, classroom oriented innovative practices" (Murray, 2009, p. 23).

\section{Acknowledgments}

We would like to express our sincere gratitude and appreciation to Hussain Al- Houssawi, Osman Z. Barnawi, Hussam Rajab for their encouraging words, feedback and comments on the early versions of this paper. We appreciate their academic support and words of wisdom whenever it was needed or even not called for.

\section{References}

Alptekin, C., \& Alptekin, M. (2013). The question of culture: EFL teaching in non-English-speaking countries. Oxford Journals, October.

Ariffin, S. (2006). Culture in EFL Teaching: Issues and Solutions. HPU TESOL Working Paper Series, 4(1), 75-78. Retrieved December $15, \quad 2013$ from http://www.mendeley.com/profiles/aunurrahman-aunurrahman/publications/journal/

Cambridge English for Teaching. (2010). CELTA: Syllabus and Assessment Guidelines (3rd ed.). University of Cambridge, ESOL Examination. Retrieved January 2, 2014 from http://www.cambridgeenglish.org/exams-and-qualifications/celta/

Elyas, T., \& Picard, M. (2010). Saudi Arabian Educational History: Impacts on English Language Teaching. Education, Business and Society: Contemporary Middle Eastern Issues, 3(2), 24-40. http://dx.doi.org/10.1108/17537981011047961

Elyas, T., \& Picard, M. (2012). Towards Globalized Notion of Teaching English in Saudi Arabia: A Case Study. Asia EFL, 41(2), 120-136.

Hobbs, V. (2013). 'A basic starter pack': the TESOL Certificate as a course in survival. ELT Journal, 67(2), 163-174. http://dx.doi.org/10.1093/elt/ccs078

Johnson, K. (2009). Second Language Teacher Education: A Sociocultural Perspective. NY: Routledge.

Kumararvadivelu, B. (2001). Towards a Postmethod Pedagogy. TESOL Quarterly, 35(4), 537-560. http://dx.doi.org/10.2307/3588427

Kumararvadivelu, B. (2003a). Beyond Methods: Macrostrategies for Language Teaching. New Haven, CT: Yale University Press.

Kumararvadivelu, B. (2003b). Critical language pedagogy: A postmethod perspective on English Language Teaching. World Englishes, 22(4), 539-550. http://dx.doi.org/10.1111/j.1467-971X.2003.00317.x

Kumararvadivelu, B. (2006a). Dangerous liaison: globalization, empire and TESOL. In J. Edge (Ed.), (Re-)locating TESOL in an Age of Empire (pp. 1-27). Houndmills, Basingstoke, Hampshire and NY: 
Palgrave Macmillan.

Kumararvadivelu, B. (2006b). TESOL methods: Changing tracks, challenging trends. TESOL Quarterly, 40(1), 59-81. http://dx.doi.org/10.2307/40264511

Kumararvadivelu, B. (2012). Language Teacher Education for a Global Society: A Modular model for knowing, Analysing, Recognizing, Doing and Seeing. NY: Routledge.

Liu, D. (1998). Ethnocentrism in TESOL: Teacher education and the neglected needs of international TESOL students. ELT Journal, 52(1), 3-10. http://dx.doi.org/10.1093/elt/52.1.3

Matsuda, A. (2003). Incorporating world Englishes in teaching English as an international language. TESOL Quarterly, 37(4), 719-729. http://dx.doi.org/10.2307/3588220

McKay, S. (2003). Toward an appropriate EIL Pedagogy: Re-examining common ELT assumptions. International Journal of Applied Linguistics, 13(1), 1-22. http://dx.doi.org/10.1111/1473-4192.00035

Murray, J. (2009). Teacher competencies in the post-method landscape: The limits of competency-based training in TESOL Teacher Education. Prospect: An Australian Journal of TESOL, 24(1), 17-29.

Pennycook, A. (1989). The concept of method, interested knowledge, and the politics of language. TESOL Quarterly, 23, 589-618. http://dx.doi.org/10.2307/3587534

Phillipson, R. (2008). Linguistic imperialism. Oxford University Press.

Prabhu, N. S. (1990). There is no best method - why? TESOL Quarterly, 24, 161-176. http://dx.doi.org/10.2307/3586897

Troudi, S. (2005). Critical content and cultural knowledge for teachers of English to Speakers of Other Languages. Teacher Development, 9(1), 115-129. http://dx.doi.org/10.1080/13664530500200233

\section{Copyrights}

Copyright for this article is retained by the author(s), with first publication rights granted to the journal.

This is an open-access article distributed under the terms and conditions of the Creative Commons Attribution license (http://creativecommons.org/licenses/by/3.0/). 